\title{
Supercritical Synthesis of Ethyl Esters via Transesterification from Waste Cooking Oil Using a Co-Solvent
}

\author{
Tapaswy Muppaneni, Harvind K. Reddy, Shuguang Deng* \\ Chemical Engineering Department, New Mexico State University, Las Cruces, USA \\ Email: ${ }^{\text {sdeng@nmsu.edu }}$
}

Received 30 July 2015; accepted 5 September 2015; published 8 September 2015

Copyright (C) 2015 by authors and Scientific Research Publishing Inc.

This work is licensed under the Creative Commons Attribution International License (CC BY).

http://creativecommons.org/licenses/by/4.0/

(c) (i) Open Access

\begin{abstract}
Biofuels became more promising alternative to the fossil fuels because of the depletion of fossil resources, renewability, environmental benefits, and energy security. Ethanolysis of waste cooking oil with hexane as co-solvent was carried out for the production of fatty acid ethyl ester (FAEE). This process reduced the severity of process parameters with high purity biodiesel yield. Process variables such as co-solvent ratio, ethanol to oil molar ratio, reaction temperature and reaction time were optimized. The maximum biodiesel yield of $88 \%$ was obtained at ethanol/oil molar ratio of 40:1, co-solvent (hexane) to oil ratio of $0.2 \%(\mathrm{v} / \mathrm{v})$, reaction temperature of $300^{\circ} \mathrm{C}$ in $20 \mathrm{~min}$ of reaction time. Fatty acid ethyl ester (biodiesel) samples produced from this process were measured and evaluated using GC-MS analytical instrument. Thermo gravimetric analysis (TGA) was also performed to examine the thermal stability of waste cooking oil, ethyl esters and fuel blends. Fuel properties of ethyl esters were determined and compared with the ASTM standards for biodiesel, regular diesel and ethyl esters from different feedstock.
\end{abstract}

\section{Keywords}

Fatty Acid Ethyl Esters, Supercritical Ethanolysis, Co-Solvent, Waste Cooking Oil

\section{Introduction}

The depletion of fossil fuels, increasing demand for energy due to rapid development and environmental problems raised by the use of fossil fuels are the main problems for the developing and developed countries. Due to limited amounts of fossil fuels and concerns about global warming, there is an increasing urge to develop more renewable energy sources. Biodiesel is one of the promising alternatives that can replace a part of the transporta-

*Corresponding author.

How to cite this paper: Muppaneni, T., Reddy, H.K. and Deng, S.G. (2015) Supercritical Synthesis of Ethyl Esters via Transesterification from Waste Cooking Oil Using a Co-Solvent. Journal of Environmental Protection, 6, 986-994.

http://dx.doi.org/10.4236/jep.2015.69087 
tion fuels. Biodiesel produces lower emissions compared to that of regular petroleum-based fuels. Replacement of regular diesel fuel with biodiesel can reduce emissions such as $\mathrm{SO}_{\mathrm{x}}, \mathrm{CO}$, particulate matter and hydrocarbons in the exhaust gas [1]. Biodiesel is a nontoxic, renewable, biodegradable, and eco-friendly fuel than can be produced from a wide range of feedstock including vegetable oils, animal fats, oil seed plants, microalgae and different other renewable sources [2] [3].

Edible vegetable oils are potential feedstock which accounts for 95\% of the world's biodiesel production [4]. But the usage of the edible vegetable oils for biodiesel production may directly impact the rise in the food prices. In this point of view, waste cooking oil or waste frying oil can serve as a potential feedstock for the production of biodiesel. This readily available and cheap waste cooking oil can be obtained anywhere around the world. According to environmental protection agency (EPA), hotels and restaurants produce around 3 billion gallons of waste cooking oil per year in the United States [5]. The amount of waste cooking oil collected in Europe is estimated around 700,000 - 1,000,000 tons/year [6]. The disposal of these large amounts of waste oils is a serious problem in many countries around the world. Considering the environmental impact on the disposal of waste cooking oils, many developed countries have set policies to penalize the disposal of waste cooking oil to the waste drainage [7]. These problems can be solved by using these waste oils as fuels by converting them into biodiesel.

Different methods can be implemented to produce biodiesel from waste cooking oil. Transesterification is one of the simplest process in which the triglycerides present in the vegetable oils chemically react with alcohol (solvent) to produce alkyl esters and glycerol with or without the aid of catalyst. Ethanol has some good properties such as high dissolving power for oils, high heat content and more over can be produced from agricultural resources. So, this can be utilized as a solvent for the transesterification process. Based on the type of catalyst used in the process, transesterification is categorized into alkali, acid and enzyme catalytic processes. All these processes have their limitations and challenges. Transesterification can also be done without the aid of catalyst at supercritical alcohol region [8]-[10]. This is a high energy consuming process because it involves high temperature and pressures.

In the production of biodiesel, reducing the mass transfer between the oil and solvent is very important as it increases the reaction rate of the transesterification process [11]. Addition of co-solvent into the reaction mixture changes the two-phase system to a single phase and increases the mass transfer between reactants [12]. The introduction of co-solvents like hexane, carbon dioxide, and calcium oxide to the reaction mixture decreases the severity of the reaction parameters and can make this process viable for large-scale industrial applications [13]. The addition of co-solvents can reduce the molar ratio of alcohol to oil for transesterification reactions and simultaneously decrease the critical point of alcohol and allow the supercritical reactions to be carried out at milder temperatures [14].

In the present study, waste cooking oil has been transesterified to produce ethyl esters (biodiesel) with ethanol as a solvent and hexane as co-solvent. Different process parameters such as co-solvent to oil ratio, ethanol to oil ratio, reaction temperature and reaction time were optimized. The thermal stability of the ethyl esters produced and fuel blends (B100, B80, B40, and B10) was tested using thermo gravimetric analyzer. Gas chromatography was used to analyze the ethyl esters and was compared with ethyl esters produced from different feedstock. The fuel properties were determined and were compared with ASTM biodiesel standards.

\section{Experimental}

\subsection{Materials and Methods}

Waste cooking oil was obtained from a local restaurant in Las Cruces, NM. Absolute ethanol was procured from Pharmaco-AAPER and commercial alcohols, Brookfield, CT. HPLC grade n-hexane and aniline were obtained from Acros organics, New Jersey. The supercritical ethanol process was carried out in the PARR 4593 Micro reactor with a 4843-controller (Parr Instrument Company, Illinois, USA). The Instrument can be operated up to $350^{\circ} \mathrm{C}$ and 120 bars. The experimental protocol by patil et al., [15] was used as the experimental procedure for transesterification of waste cooking oils using hexane as co-solvent in this work and all the experiments were done in three replicates.

\subsection{Transesterification Mechanism}

Transesterification of triglycerides/oils to yield ethyl ester at supercritical condition is shown in Figure 1. In the 


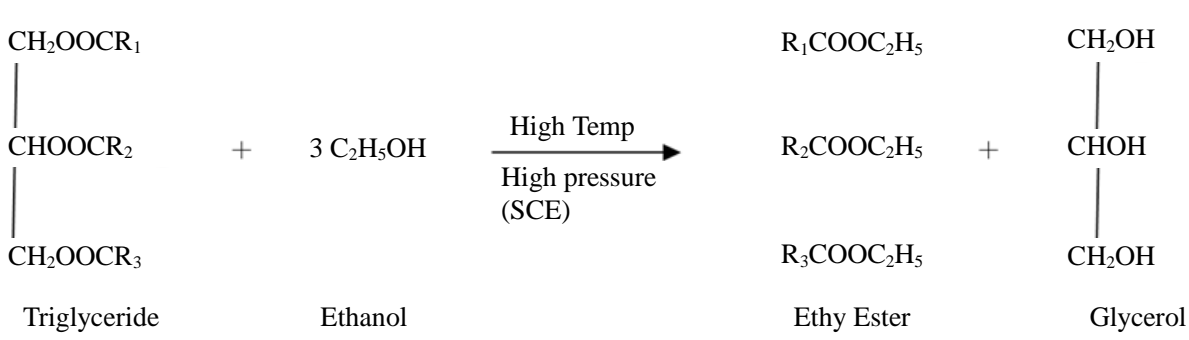

$\mathrm{R}_{1}, \mathrm{R}_{2}$ and $\mathrm{R}_{3}$ are long chain hydrocarbons which may be same or different.

Figure 1. Transesterification reaction under supercritical ethanol conditions to yield ethyl ester.

supercritical state, depending on pressure and temperature, the intermolecular hydrogen bonding in the ethanol molecule will be significantly decreased. As a result, the polarity and dielectric constant of ethanol are reduced allowing it to act as a free monomer. Subsequently, ethanol at supercritical conditions can solvate the non-polar triglycerides to form a single phase of vegetable oil/ethanol mixture and yield fatty acid ethyl ester and diglycerides. In a similar way, diglyceride is transesterified to form ethyl ester and monoglyceride, which is converted further to ethyl ester and glycerol in the last step.

\subsection{Analytical Methods}

The ethyl ester samples were analyzed by a GC-MS system incorporated with an Agilent 5975 C MSD (TripleAxis Detector) and an Agilent 7890 A GC equipped with a capillary column (HP-5 MS, 5\% phenyl methyl silox $30 \mathrm{~m} \times 250 \mu \mathrm{m} \times 0.25 \mu \mathrm{m}$ nominal). Approximately, $1 \mu \mathrm{L}$ sample was injected into the GC. Helium was used as the carrier gas. The injection was performed in split mode (20:1). The parameters of the oven temperature program consist of: start at $50^{\circ} \mathrm{C}$ with $10^{\circ} \mathrm{C} / \mathrm{min}$ intervals up to $220^{\circ} \mathrm{C}(1 \mathrm{~min})$ and up to $250^{\circ} \mathrm{C}$ with $5^{\circ} \mathrm{C} / \mathrm{min}$ intervals $(2 \mathrm{~min})$. The temperatures of the injector and detector were set at $250^{\circ} \mathrm{C}$. Thermogravimetric analysis (TGA) of waste cooking oil, ethyl esters (FAEE) and fuel blends was performed using Perkin Elmer Pyris 1 TGA. The samples were heated from $25^{\circ} \mathrm{C}$ to $950^{\circ} \mathrm{C}$ at constant heating rate of $10^{\circ} \mathrm{C} / \mathrm{min}$ in an atmosphere of nitrogen at a constant purge rate of $20 \mathrm{~mL} / \mathrm{min}$ at the pan.

\section{Results and Discussion}

\subsection{Effect of Co-Solvent on Ethyl Ester Yield}

Hexane was added into the reactant mixture to enhance the formation of a single phase between ethanol and oil and to accelerate the reaction rate at the supercritical condition [15]. Addition of co-solvent into the reaction mixture changes the two phase system to a single phase system. This increases the mass transfer in the reaction mixture and therefore the production of ethyl esters will be intensified [12]. The effect of co-solvent on the production of ethyl esters was studied at $40: 1$ ethanol to oil ratio, $300^{\circ} \mathrm{C}$ temperature, pressure above 80 bars and co-solvent to oil ratios ranging from 0 to $0.3(\mathrm{v} / \mathrm{v})$. As shown in Figure 2, waste cooking oil ethyl ester yield (WEE) was $66 \%$ without hexane and increased to $77 \%$ at a co-solvent ratio of $0.05(\mathrm{v} / \mathrm{v})$ and $89 \%$ at $0.2(\mathrm{v} / \mathrm{v})$ co-solvent ratio respectively. The maximum ester yield of $88 \%$ was obtained for the waste cooking oil (WEE) at a co-solvent ratio of $0.2(\mathrm{v} / \mathrm{v})$. Further increase in the co-solvent did not have any significant effect on the ester yield. It indicates that the addition of a little amount of hexane could increase the yield substantially. From previous study, it was observed that with the increment of hexane to ethanol ratio could reduce the severe optimum operating condition of supercritical ethanol (SCE) drastically [15]. Considering these parameters, it is obvious to conclude that hexane as co-solvent has a high potential to be used in the supercritical alcohol technology. Pressure above 80 bar and optimum co-solvent to oil ratio of $0.2(\mathrm{v} / \mathrm{v})$ was taken for studying other process parameters including ethanol to oil molar ratio, reaction temperature and reaction time.

\subsection{Effect of Ethanol to Oil Molar Ratio on Ethyl Ester Yield}

Ethanol to oil molar ratio is one of the important parameters that influences the ethyl ester yield. A higher molar 


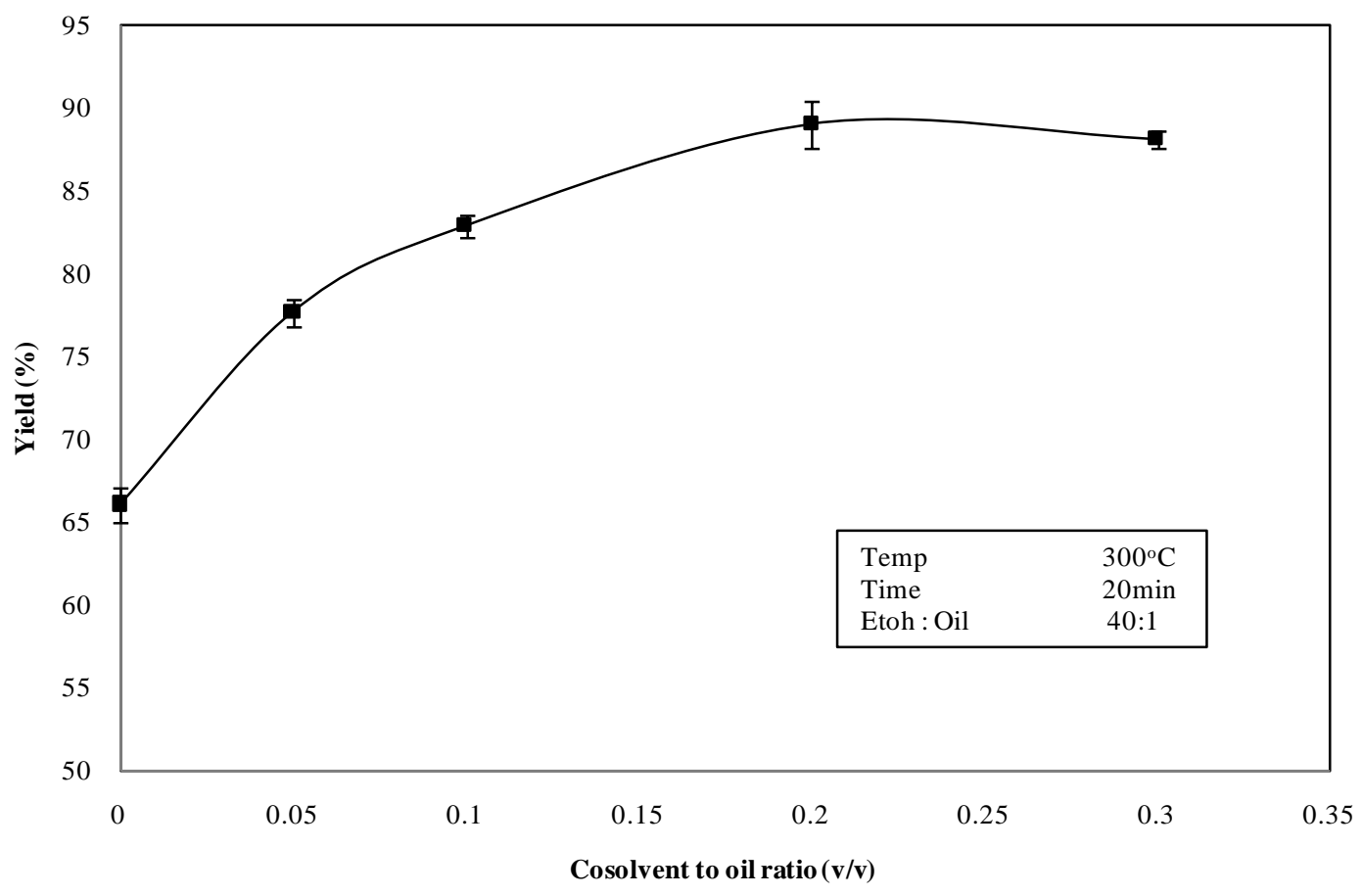

Figure 2. Effect of co-solvent (hexane) to oil ratio on ethyl ester yield.

ratio is required to drive the reaction toward completion at a faster rate and shift the equilibrium towards the product side in non-catalytic supercritical alcohol condition [16]. The experiments were conducted by varying the ethanol to oil malar ratios between $25: 1$ and $55: 1$ by maintaining the temperature at $300^{\circ} \mathrm{C}$ for 20 min of reaction time. Figure 3 shows that the ester yield increased with increasing ethanol to oil molar ratio due to increased contact area between ethanol and oil and increased mutual solubility in the presence of co-solvent. With the strong affinity of ethanol for dissolving oils, maximum WEE yield was obtained at ethanol to oil molar ratio of 40:1. At higher levels, an excess ethanol started to interfere with the glycerin separation due to increased solubility, which resulted in lower biodiesel yields [17]. Similar results were shown for the supercritical methanol transesterification cottonseed oil with higher yields [18]. This might be due to ethanol having better solvent properties, forms an emulsion after the transesterification reaction which reduces the biodiesel yield in SCE process after separation [19].

\subsection{Effect of Reaction Temperature on Ethyl Ester Yield}

The effect of reaction temperature on ester yield was studied at different temperatures varied from $245^{\circ} \mathrm{C}$ to $320^{\circ} \mathrm{C}$ with ethanol to oil ratio for waste cooking oil, co-solvent (hexane) to oil ratio of $0.2(\mathrm{v} / \mathrm{v})$, and the reaction pressure of 80 bar for 20 min of reaction time. Figure 4 shows the influence of reaction temperature on ethyl ester yield at supercritical ethanol conditions. As shown in Figure 4, at low reaction temperature, the yield was found to be low and increased rapidly as reaction temperature increased. It was observed that increasing the reaction temperature, especially at the supercritical condition, has favored the biodiesel yield [20]. Maximum ethyl ester yield of $88 \%$ for waste cooking oil was obtained at $300^{\circ} \mathrm{C}\left( \pm 5^{\circ} \mathrm{C}\right)$ and started decreasing gradually at high temperatures due to the decomposition of ethyl esters above $300^{\circ} \mathrm{C}$.

\subsection{Effect of Reaction Time on Ethyl Ester Yield}

Reaction time plays a crucial role in ethyl ester production as it can influence the productivity and economic consideration. Transesterification experiments for waste cooking oil were carried out at a constant agitation speed for different time periods between 5 and $30 \mathrm{~min}$. A longer reaction time allows the transesterification reaction to proceed to completion and results in a higher yield of ethyl esters. The reaction time was varied by taking ethanol to oil ratio of $40: 1$, co-solvent (hexane) to oil ratio of $0.2(\mathrm{v} / \mathrm{v})$, temperature of $300^{\circ} \mathrm{C}$ and the 


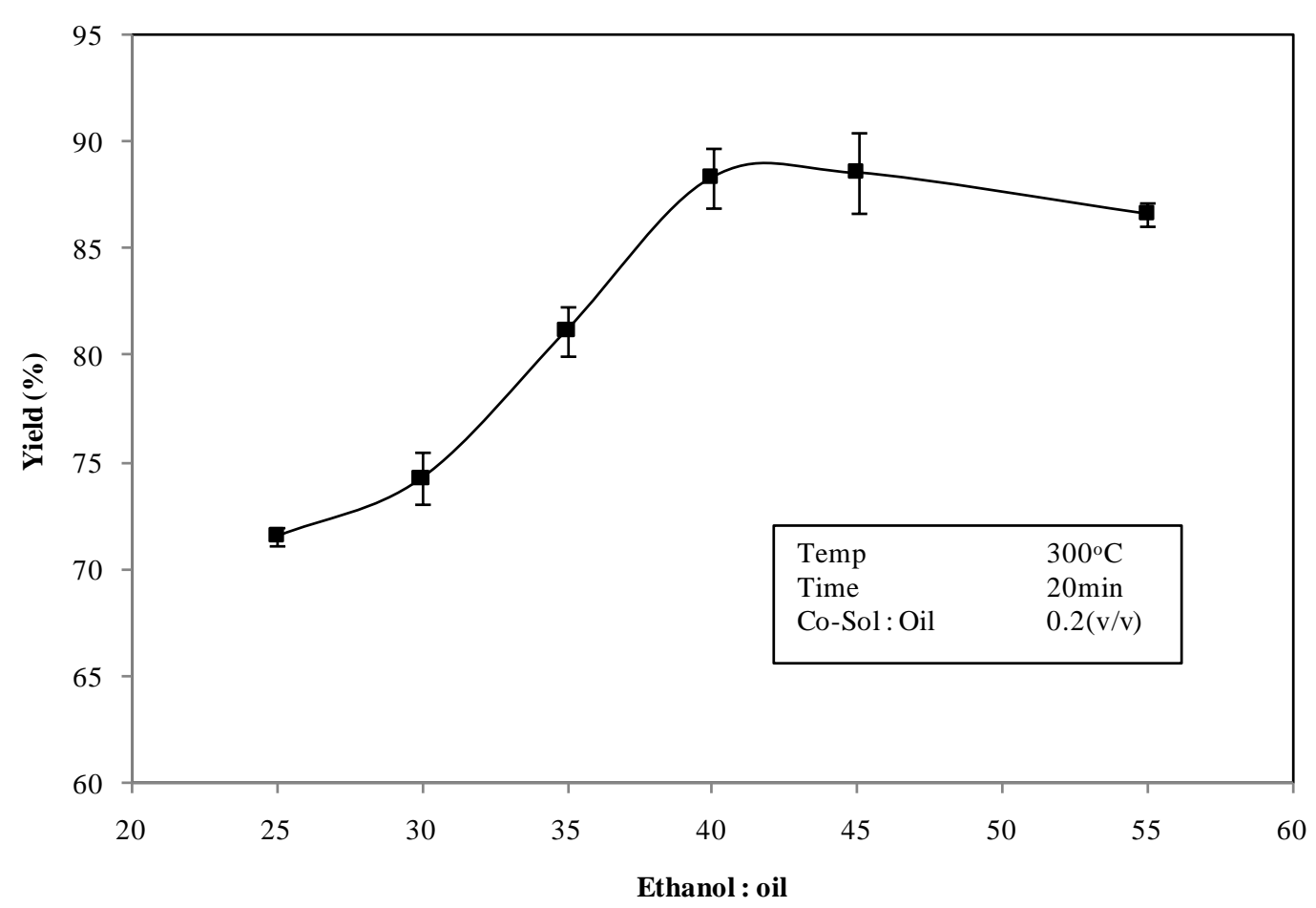

Figure 3. Effect of ethanol to oil molar ratio on ethyl ester yield.

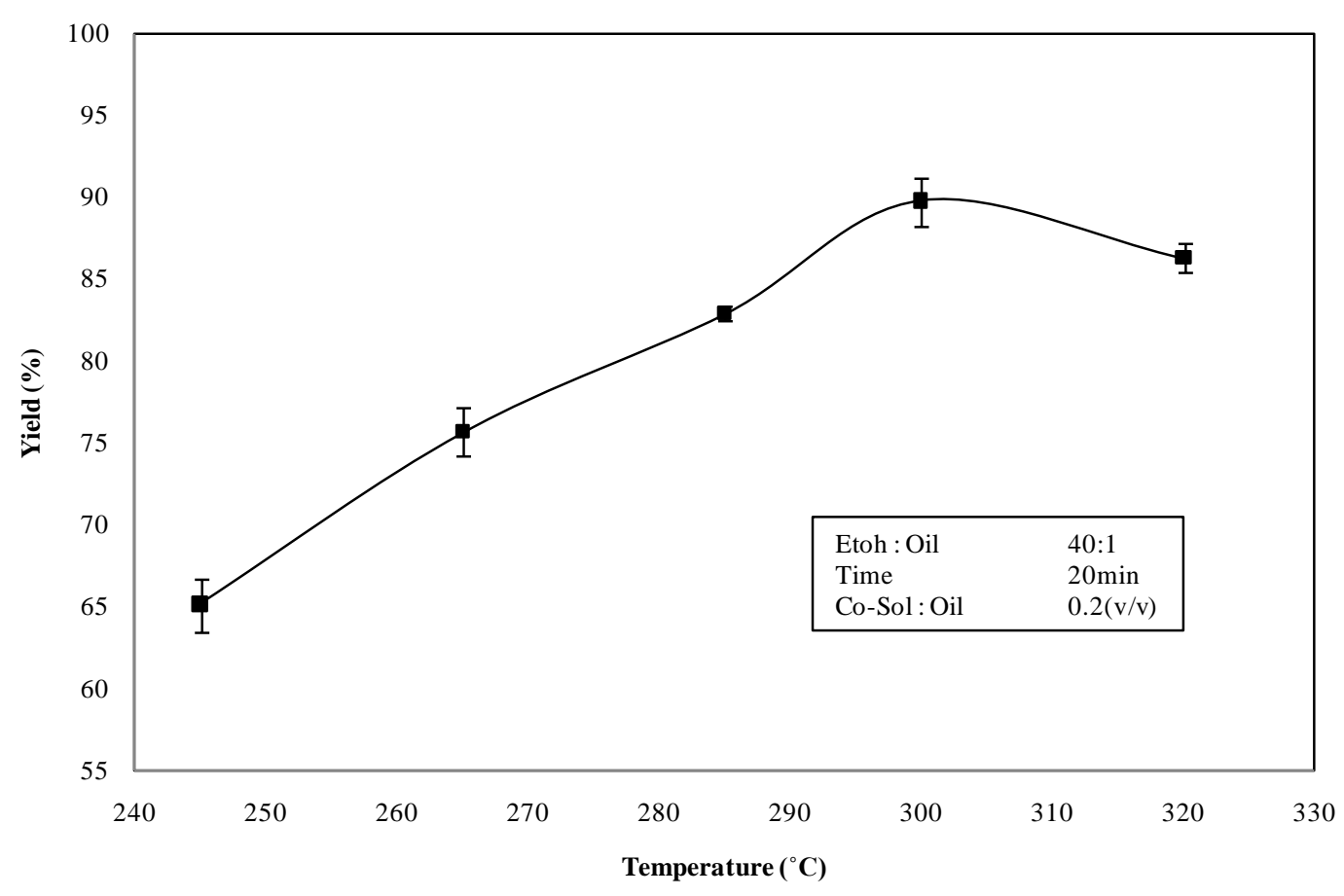

Figure 4. Effect of reaction temperature on ethyl ester yield.

reaction pressure of 80 bar. Figure 5 shows that the ester yield was increased from $73 \%$ to around $88 \%$ for waste cooking oil in the time interval of $5 \mathrm{~min}$ to $20 \mathrm{~min}$. For supercritical ethanol transesterification, $20 \mathrm{~min}$ of reaction time are sufficient to achieve maximum yield of ethyl esters for waste cooking oils. Extending the reaction period in supercritical ethanol reaction will not affect the yield significantly due to inferior reactivity of ethanol and lower optimum temperature. 


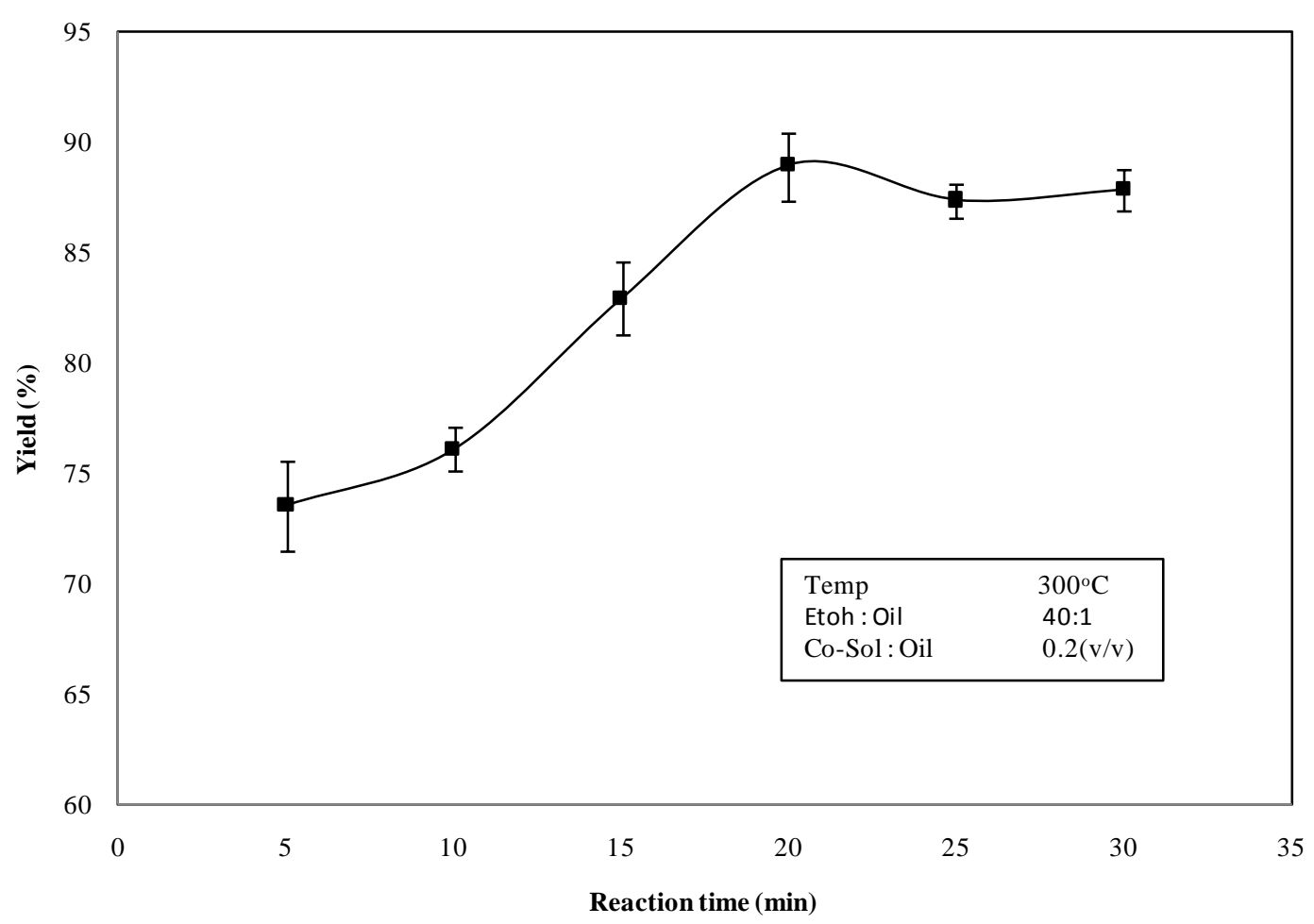

Figure 5. Effect of reaction time on ethyl ester yield.

\section{Analysis of Ethyl Esters}

\subsection{Thermogravimetric Analysis}

The viscosity and the volatilization temperatures of the oils should be reduced in order to use them as fuels. Thermogravimetric analysis is a quick, easy and useful technique to measure the onset volatilization temperatures of oils and ethyl esters [21] [22]. Figure 6 shows the Thermogravimetric (TG) curves of waste cooking oil and ethyl esters compared to diesel fuel blends. Different ethyl ester-diesel fuel blends such as B100 (100\% ethyl esters), B80 ( $80 \%$ ethyl esters blended with $20 \%$ petroleum diesel fuel), B40 (40\% ethyl esters blended with $60 \%$ petroleum diesel fuel) and B10 (10\% ethyl esters blended with 90\% petroleum diesel fuel) were analyzed for the thermal stability. From the TG curves, the volatilization of waste cooking oil, waste cooking oil ethyl esters and fuel blends started at around $350^{\circ} \mathrm{C}, 140^{\circ} \mathrm{C}-150^{\circ} \mathrm{C}$ and $90^{\circ} \mathrm{C}-140^{\circ} \mathrm{C}$ respectively. This can be observed by the initial weight loss of the samples in the Figure 6. High viscosity and molecular tension produced by bulky triglyceride molecule in the oil samples could be the reason for slow degradation process and thermal stability for the waste cooking oil [23]. The temperature difference between the oil and esters for thermal degradation shows the extent of the transesterification done during the process. Hence, the supercritical transesterification is a suitable way to convert the vegetable oils into potential alternatives for diesel fuel.

\subsection{Gas Chromatography-Mass Spectrometry}

The fatty acid ethyl ester composition in the waste cooking oil after the transesterification was compared with the previous studies and was shown in Table 1 [3] [24]. Table 1 shows the fatty acid ethyl ester composition of camelina ethyl ester (CEE), palm oil ethyl ester (PEE) and waste cooking ethyl esters (WEE). The major fatty acid ethyl esters found in CEE were reported as C18:1, C18:2, C18:3 and C20:1. Whereas WEE has mostly C16:0, C18:1, and C18:2. From the table, the PEE has around 50\% of saturated and 50\% of unsaturated ethyl esters of total FAEE which exhibits poor pour point properties. This can be solved by blending the PEE with diesel fuel or by adding pour point depressants [24]. The total percentage of unsaturated ethyl esters contributed to around $85 \%$ in CEE and 82\% in WEE of total FAEE which favors the pour and cloud point properties of ethyl esters produced, but has adverse influence on several fuel properties such as oxidation stability and ignition 


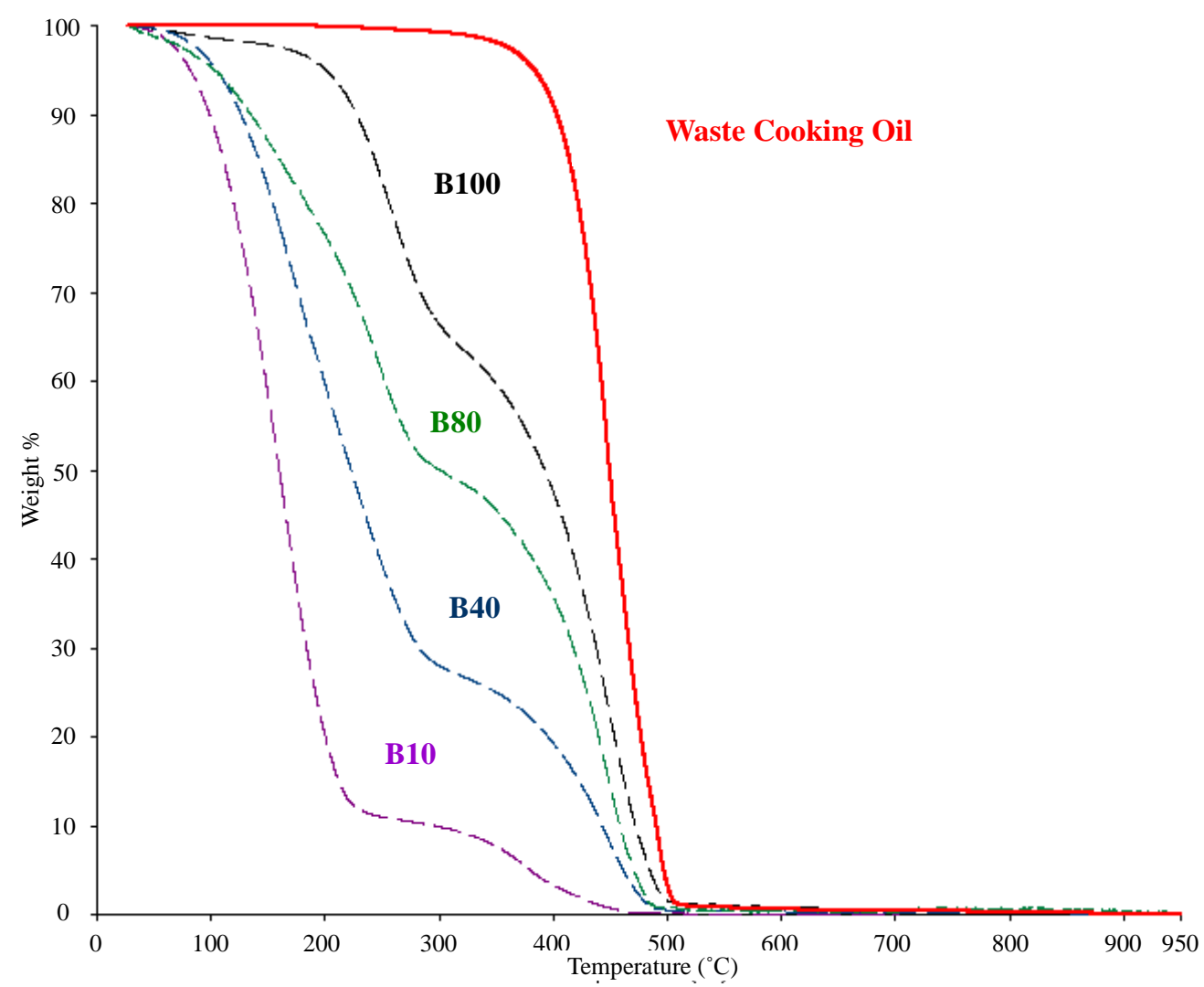

Figure 6. Overlay of thermogravimetric curves for waste cooking oil, B100, B80, B40 and B10.

Table 1. Fatty acid ethyl ester composition in camelina, palm and waste cooking ethyl esters.

\begin{tabular}{|c|c|c|c|c|}
\hline \multirow{2}{*}{ Fatty acid ethyl ester } & \multirow{2}{*}{ Common name } & \multicolumn{3}{|c|}{ wt.\% } \\
\hline & & $\mathrm{CEE}^{\mathrm{a}}[3]$ & $\mathrm{PEE}^{\mathrm{b}}[24]$ & $W^{\prime} E^{c}$ \\
\hline Hexadecanoic acid ethyl ester & Palmitic acid, C16:0 & 5.99 & 44.64 & 12.05 \\
\hline Octadecanoic acid ethyl ester & Stearic acid, C18:0 & 2.33 & - & 5.12 \\
\hline cis-9-Octadecenoic acid ethyl ester & Oleic acid ,C18:1 n9 & 18.61 & 5.82 & 31.94 \\
\hline cis-9,12-Octadecadienoic acid ethyl ester & Linoleic acid, C18:2 n6 & 19.48 & 2.15 & 47.56 \\
\hline cis-9,12,15-Octadecatrienoic acid ethyl ester & Linolenic acid, C18:3 n3 & 26.66 & 42.67 & 2.88 \\
\hline Eicosanoic acid ethyl ester & Arachidic acid, C20:0 & 1.38 & 4.72 & - \\
\hline cis-11-Eicosanoic acid ethyl ester & C20:1 & 20.18 & - & - \\
\hline Others & - & 5.37 & - & 0.45 \\
\hline
\end{tabular}

${ }^{\mathrm{a} C}$ Camelina oil ethyl ester; ${ }^{\mathrm{b}} \mathrm{Palm}$ oil ethyl ester; ${ }^{\mathrm{c}}$ Waste cooking oil ethyl ester.

quality of fuel. The extent of unsaturation of FAEE which makes it susceptible to oxidation during storage can be reduced easily by partial catalytic hydrogenation of the oil or by adding suitable synthetic anti-oxidants [25].

\subsection{Fuel Properties of Ethyl Esters}

The fuel properties of waste cooking oil ethyl esters were compared with camelina and palm oil derived ethyl esters and respective testing methods are given in Table 2. Most of the fuel properties of ethyl esters are comparable to that of ASTM biodiesel standards [26]. The viscosity of ethyl esters produced was comparable to regular diesel viscosity. Hence, no hardware modifications are required for handling this fuel in existing engines. 
Table 2. Comparison of fuel properties of ethyl esters from different feedstock.

\begin{tabular}{cccccccccc}
\hline Properties & $\begin{array}{c}\text { Camelina } \\
\text { oil }\end{array}$ & $\begin{array}{c}\text { Palm } \\
\text { oil }\end{array}$ & $\begin{array}{c}\text { Waste } \\
\text { cooking oil }\end{array}$ & $\begin{array}{c}\text { CEE }^{\mathrm{a}} \\
{[3]}\end{array}$ & $\begin{array}{c}\text { PEE }^{\mathrm{b}} \\
{[24]}\end{array}$ & WEE $^{\mathrm{c}}$ & $\begin{array}{c}\text { Biodiesel standard } \\
\text { ASTM D 6751-08 }\end{array}$ & $\begin{array}{c}\text { Regular } \\
\text { diesel }\end{array}$ & $\begin{array}{c}\text { Testing ASTM } \\
\text { method }\end{array}$ \\
\hline Specific gravity & 0.91 & 0.92 & 0.92 & 0.87 & 0.88 & 0.88 & $0.87-0.90$ & 0.85 & D287 \\
Pour point $\left({ }^{\circ} \mathrm{C}\right)$ & -23 & 14 & -12 & -15 & 13 & -7 & -15 to 10 & -20 & D97 \\
$\begin{array}{c}\text { Cetane number } \\
\text { Viscoscity }\left(\mathrm{mm}^{2} / \mathrm{s}\right)\end{array}$ & 35 & 40 & 32 & 52 & 51 & 54 & 47 min. & 46 & D613 \\
at $40^{\circ} \mathrm{C}$ & 14 & 38 & 29 & 4.87 & 5.42 & 4.89 & $1.9-6.0$ & 2.6 & D445 \\
\hline
\end{tabular}

${ }^{\mathrm{a} C a m e l i n a ~ o i l ~ e t h y l ~ e s t e r ; ~}{ }^{\mathrm{b}} \mathrm{Palm}$ oil ethyl ester; ${ }^{\mathrm{c}}$ Waste cooking oil ethyl ester.

The estimated cetane numbers were found to be higher than ASTM biodiesel standards. A higher cetane number indicates a good ignition quality of fuel. In a particular diesel engine, higher cetane fuels will have shorter ignition delay periods than lower cetane fuels. The fluidity of fuel in an engine is a crucial factor to ensure its efficient performance. The freezing point of biodiesel fuel increases with increasing carbon atoms in the carbon chain and decreases with increasing double bonds [27] [28]. The pour point of WEE was determines as $7^{\circ} \mathrm{C}$. This pour point might give rise to low running problems in the cold season, which could be overcome by the addition of suitable pour point depressants, flow improvers, paraffin inhibitor, or by blending with diesel oil.

\section{Conclusion}

Transesterification of waste cooking oils at supercritical ethanol conditions with hexane as co-solvent was demonstrated to yield high quantity and high purity biodiesel fuel in shorter reaction time. A maximum yield of $88 \%$ was obtained for the ethyl ester production. The optimum conditions for the production of waste cooking oil ethyl esters were $300^{\circ} \mathrm{C}$ reaction temperature, reaction time of $20 \mathrm{~min}$, ethanol/oil molar ratio of $40: 1$ and co-solvent (hexane) to oil ratio of $0.2 \%(\mathrm{v} / \mathrm{v})$. The fuel properties of biodiesel produced from this feedstock meet the ASTM biodiesel standards and are comparable to those of the regular diesel fuels. So, this fuel can be directly used in vehicles with minimal or no modifications to the engine. This transesterification route greatly simplifies the downstream processes and leads to a substantial cost saving in biodiesel production. The use of green solvent (ethanol) makes the process sustainable and renewable.

\section{Acknowledgements}

We gratefully acknowledge financial support from US Air Force Research Laboratory (FA8650-11-C-2127), US Department of Energy (DE-EE0003046) and New Mexico State University Office of Vice President for Research.

\section{References}

[1] Krisada, N., Pisitpong, I., Apanee, L. and Samai, J.I. (2009) A Comparative Study of $\mathrm{KOH} / \mathrm{Al}_{2} \mathrm{O}_{3}$ and KOH/NaY Catalysts for Biodiesel Production via Transesterification from Palm Oil. Renewable Energy, 34, 1145-1150. http://dx.doi.org/10.1016/j.renene.2008.06.015

[2] Antolin, G., Tinaut, F., Briceno, Y., Castano, V., Perez, C. and Ramirez, A. (2002) Optimization of Biodiesel Production by Sunflower Oil Transesterification. Bioresource Technology, 83, 111-114. http://dx.doi.org/10.1016/S0960-8524(01)00200-0

[3] Muppaneni, T., Reddy, H.K., Patil, P.D., Dailey, P., Aday, C. and Deng, S. (2012) Ethanolysis of Camelina Oil under Supercritical Condition with Hexane as a Co-Solvent. Applied Energy, 94, 84-88. http://dx.doi.org/10.1016/j.apenergy.2012.01.023

[4] Gui, M.M., Lee, K.T. and Bhatia, S. (2008) Feasibility of Edible Oil vs. Non-Edible Oil vs. Waste Edible Oil as Biodiesel Feedstock. Energy, 33, 1646-1653. http://dx.doi.org/10.1016/j.energy.2008.06.002

[5] http://www.epa.gov/region9/waste/biodiesel/questions.html

[6] Supple, B., Holward-Hildige, R., Gonzalez-Gomez, E. and Leashy, J.J. (2002) The Effect of Stream Treating Waste Cooking Oil on the Yield of Methyl ester. Journal of the American Oil Chemists' Society, 79, 175-178. http://dx.doi.org/10.1007/s11746-002-0454-1 
[7] Kulkarni, M.G. and Dalai, A.K. (2006) Waste Cooking Oil—An Economical Source for Biodiesel, a Review. Industrial \& Engineering Chemistry Research, 45, 2901-2913. http://dx.doi.org/10.1021/ie0510526

[8] Saka, S. and Kusdiana, D. (2001) Biodiesel Fuel from Rapeseed Oil as Prepared in Supercritical Methanol. Fuel, 80, 225-231. http://dx.doi.org/10.1016/S0016-2361(00)00083-1

[9] Demirbas, A. (2002) Biodiesel from Vegetable Oils with MgO Catalytic Transesterification in Supercritical Methanol. Energy Conversion and Management, 43, 2349-2356. http://dx.doi.org/10.1016/S0196-8904(01)00170-4

[10] Demirbas, A. (2005) Biodiesel Production from Vegetable Oils via Catalytic and Non-Catalytic Supercritical Methanol Transesterification Methods. Progress in Energy and Combustion Science, 31, 466-487. http://dx.doi.org/10.1016/j.pecs.2005.09.001

[11] Alenezi, R., Santos, R.C.D., Raymahasay, S. and Leeke, G.A. (2013) Improved Biodiesel Manufacture at Low Temperature and Short Reaction Time. Renewable Energy, 53, 242-248. http://dx.doi.org/10.1016/j.renene.2012.11.019

[12] Maddikeri, G.L., Pandit, B.A. and Gogate, R.P. (2012) Intensification Approaches for Biodiesel Synthesis from Waste Cooking Oil: A Review. Industrial \& Engineering Chemistry Research, 51, 14610-14628. http://dx.doi.org/10.1021/ie301675j

[13] Yin, J.Z., Xiao, M. and Song, J.B. (2008) Biodiesel from Soybean Oil in Supercritical Methanol with Co-Solvent. Energy Conversion and Management, 49, 908-912. http://dx.doi.org/10.1016/j.enconman.2007.10.018

[14] Han, H.W., Cao, W.L. and Zhang, J.C. (2005) Preparation of Biodiesel from Soybean Using Supercritical Methanol and $\mathrm{CO}_{2}$ as Co-Solvent. Process Biochemistry, 40, 3148-3151. http://dx.doi.org/10.1016/j.procbio.2005.03.014

[15] Patil, P.D., Gude, V.G. and Deng, S. (2010) Transesterification of Camelina Sativa Oil Using Supercritical and Subcritical Methanol with Cosolvents. Energy \& Fuels, 24, 746-751. http://dx.doi.org/10.1021/ef900854h

[16] Freedman, B., Butterfield, R.O. and Pryde, E.H. (1986) Transesterification Kinetics of Soybean Oil. Journal of the American Oil Chemists' Society, 63, 1375-1380. http://dx.doi.org/10.1007/BF02679606

[17] Attanatho, L., Magmee, S. and Jenvanitpanjakul, P. (2004) Factors Affecting the Synthesis of Biodiesel from Crude Palm Kernel Oil. The Joint International Conference on Sustainable Energy and Environment (SEE), Hua Hin, 1-3 December 2004, 359-361.

[18] Garcia, M., Gonzalo, A., Sanchez, J.L., Arauzo, J. and Simoes, C. (2011) Methanolysis and Ethanolysis of Animal Fats, A Comparative Study of the Influence of Alcohols. Chemical Industry and Chemical Engineering Quarterly, 17, 91-97. http://dx.doi.org/10.2298/CICEQ100224058G

[19] Demirbas, A. (2008) Studies on Cottonseed Oil Biodiesel Prepared in Non-Catalytic SCF Conditions. Bioresource Technology, 99, 1125-1130. http://dx.doi.org/10.1016/j.biortech.2007.02.024

[20] Demirbas, A. (2007) Biodiesel from Sunflower Oil in Supercritical Methanol with Calcium Oxide. Energy Conversion and Management, 48, 937-941. http://dx.doi.org/10.1016/j.enconman.2006.08.004

[21] Oliveira, J.R., Silva, R.B., Moura, E.M. and Moura, C.V.R. (2008) Biodiesel of Tucum Oil, Synthesized by Methanolic and Ethanolic Routes. Fuel, 87, 1718-1723. http://dx.doi.org/10.1016/j.fuel.2007.09.007

[22] Patil, P.D., Gude, V.G., Reddy, H.K., Muppaneni, T. and Deng, S. (2012) Biodiesel Production from Waste Cooking Oil Using Sulfuric Acid and Microwave Irradiation Processes. Journal of Environmental Protection, 3, 107-113. http://dx.doi.org/10.4236/jep.2012.31013

[23] Lang, X., Dalai, A.K., Bakshi, N.N., Reaney, M.J. and Hertz, P.B. (2001) Preparation and Characterization of Biodiesel from Various Bio-Oils. Bioresource Technology, 80, 53-62. http://dx.doi.org/10.1016/S0960-8524(01)00051-7

[24] Muppaneni, T., Reddy, H.K., Ponnusamy, S., Patil, P.D., Sun, Y., Dailey, P. and Deng, S. (2013) Optimization of Biodiesel Production from Palm Oil under Supercritical Ethanol Conditions Using Hexane as Co-Solvent, A Response Surface Methodology Approach. Fuel, 107, 633-640. http://dx.doi.org/10.1016/j.fuel.2012.11.046

[25] Dijkstra, A. (2006) Revisiting the Formation of Trans Isomers during Partial Hydrogenation of Triacylglycerol Oils. European Journal of Lipid Science and Technology, 108, 249-264. http://dx.doi.org/10.1002/ejlt.200500335

[26] ASTM, American Standards for Testing of Materials (2008) D 189-01, D 240-02, D 4052-96, D 445-03, D 482-74, D 5555-95, D 6751-02.

[27] Goering, C.E., Schwab, A.W., Daugherty, M.J., Pryde, E.H. and Heakin, A. (1982) Fuel Properties of Eleven Vegetable Oils. Transactions of the ASABE, 25, 1472-1477. http://dx.doi.org/10.13031/2013.33748

[28] Graboski, M.S. and McCormick, R.L (1982) Combustion of Fat and Vegetable Oil Derived Fuels in Diesel Engines. Progress in Energy and Combustion Science, 24, 125-164. http://dx.doi.org/10.1016/S0360-1285(97)00034-8 